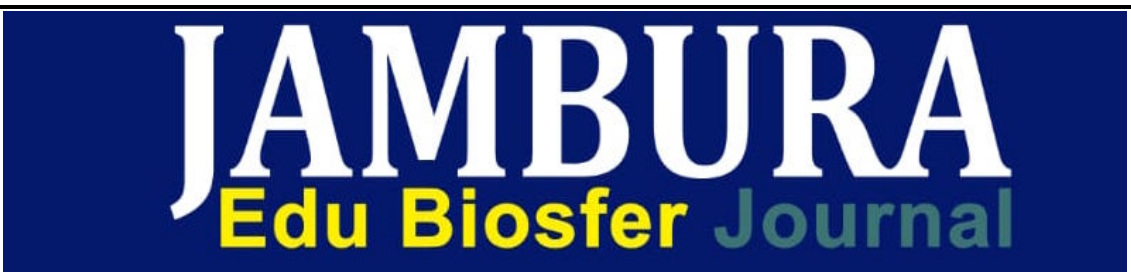

Journal homepage: http://ejurnal.ung.ac.id/index.php/edubiosfer

\title{
Pengembangan Buku Ajar Ekologi Dengan Memanfaatkan Hasil Analisis Potensi Ekosistem Mangrove Sebagai Penyerap Karbon
}

\author{
Ilyas Husain ${ }^{1}$, Ramli Utina ${ }^{2}$, Elya Nusantary ${ }^{3}$ \\ Mahasiswa Jurusan Biologi, Jl. Jenderal Sudirman No. 6, Kota Gorontalo, 96128, Indonesia \\ Dosen Prodi Pendidikan Biologi, Jl. Jenderal Sudirman No. 6, Kota Gorontalo, 96128, Indonesia \\ Dosen Prodi Pendidikan Biologi, Jl. Jenderal Sudirman No. 6, Kota Gorontalo, 96128, Indonesia
}

\begin{abstract}
Husain, Ilyas 2017 "Analysis of Mangrove Ecosystem Potential as Carbon Absorbent, For Development of Textbook Material On Ecology Course". Thesis of Graduate Program of State University of Gorontalo (UNG). The principal supervisor was. Prof. Dr. Ramli, Utina, M.Pd. and the co-supervisor was Dr. Elya Nusantari, M.Pd.

This study aims To determine the quality of textbooks based on research for the development of teaching materials on the subject of ecology subject matter and energy. Development of research-based learning tools of subject matter and Energy using $R \& D$ model through 10 steps of development then simplified on three stages, namely (1) exploration stage, (2) prototype development stage, and (3) product validation stage, As for the products produced in this study is a textbook. The resulting product development is then validated by material experts, design experts, and students. The result of the research shows that (1) textbook based on research according to the material expert from the whole aspect of assessment for the validation of textbook is $93.75 \%$ including excellent quality, because it is in the range of $81 \%$ to $100 \%$, (2) For the validation of textbook design is $91.67 \%$, including excellent quality, because it is in the range of $81 \%$ to $100 \%$, (3) student response to the overall quality of textbook aspect is at $94 \%$ percentage where this value belongs to very good category because it is In the range of 81 to $100 \%$.
\end{abstract}

Key Words: otential of Mangrove Ecosystem, Carbon Absorbent, Material Development, Textbook, Ecology,

\section{Pendahuluan}

Indonesia dikenal memiliki mangrove terluas di dunia (FAO, 2007). Di Indonesia terdapat 40 jenis mangrove sejati diantaranya spesies dari Genus Avicennia, yaitu Avicennia alba, Avicennia eucalyptifolia, Avicennia marina, dan Avicennia officinalis (Noor, et all). Berdasarkan tempat tumbuhnya hutan mangrove dapat dibedakan atas beberapa zona, salah satunya adalah zona Avicennia sp yang letaknya di luar hutan bakau, memiliki tanah yang berlumpur, lembek dan sedikit mengandung humus (Oktavianus, 2013). Avicennia sp merupakan tumbuhan pionir pada lahan pantai yang terlindung dan akarnya sering dilaporkan membantu pengikatan sedimen dan mempercepat proses pembentukan tanah timbul. Avicennia sp diketahui mampu menyerap karbon dan menyimpan dalam bentuk biomassa utamanya pada bagian akar, lebih besar dari spesies mangrove lainnya (Tamooh et al, 2008).

Bebas garam, khusus berupa tumbuh- tumbuhan disebut halofita (Halophytic vegetation) (Ghufran, 2012) atau tumbuh-tumbuhan yang memiliki kemampuan adaptasi tinggi terhadap salinitas payau dan harus hidup pada kondisi lingkungan yang demikian, sehingga spesies tumbuhannya disebut tumbuhan halophytes obligat. Mangrove sebagai salah satu sumber daya alam di kawasan pesisir, memiliki manfaat sangat luas ditinjau dari aspek ekologi, biologi dan ekonomi. Fungsi ekologi antara lain menjaga kestabilan pantai dan sebagai habitat burung, fungsi biologi sebagai 
pembenihan ikan, udang dan biota laut pemakan plankton serta sebagai areal budidaya ikan tambak, areal rekreasi dan sumber kayu sebagai fungsi ekonomi (Bismark, et al., 2008).

Mangrove memiliki kemampuan asimilasi dan laju penyerapan $\mathrm{C}$ yang tinggi (Donato, et al, 2012). Hasil penelitian Donato, et al., tahun 2012, di 25 lokasi mangrove sepanjang Indo-Pasifik menunjukkan bahwa mangrove merupakan salah satu hutan terkaya karbon di kawasan tropis, yang mengandung sekitar $1.023 \mathrm{Mg}$ karbon perhektar dan sangat tinggi dibandingkan rerata simpanan karbon dari berbagai tipe hutan lainnya di dunia. Kemampuan mangrove dalam menyerap karbon, banyak diteliti guna menyusun suatu cara efektif dalam rangka mitigasi pemanasan global akibat dari menigkatnya Gas Rumah Kaca salah satunya gas Karbondioksida (CO2).

IPCC atau Intergovernmental Panel on Climate Change (dalam Manuri, et al., 2011) mengelompokkan sumber karbon menjadi tiga kategori utama, yaitu biomassa hidup, bahan organik mati dan karbon tanah. Biomassa hidup terbagi menjadi dua bagian yaitu Biomassa Atas Permukaan (BAP) dan Biomassa Bawah Permukaan (BBP). Sedangkan bahan organik mati dikelompokkan menjadi 2 yaitu kayu mati dan serasah. Sehingga secara keseluruhan IPCC menetapkan 5 sumber karbon hutan yang perlu dihitung dalam upaya penurunan emisi akibat perubahan tutupan lahan yakni atas permukaan, bawah tanah, kayu mati, serasah, dan bahan organic tanah.

Kawasan hutan mangrove yang terdapat di wilayah pesisir Provinsi Gorontalo merupakan wilayah mangrove dengan potensi serapan karbon yang tergolong penting bagi ekosistem sekitarnya. Berdasarkan data yang diperoleh dari Dinas kehutanan bahwa vegetasi mangrove di pesisir Provinsi Gorontalo terdapat lima spesies mangrove sejati seperti Rhizophora mucronata, Rhizophora stylosa, Soneratia alba, Bruguiera sp. Jenis yang paling banyak ditemui adalah Rhizophora mucronata, Rhizophora stylosa, Avicennia marina, Bruguiera sp dan Soneratia alba.

Dengan perkembangan dunia pendidikan dan tuntutan Kurikulum di Perguruan Tinggi, maka perlu pengembangan bahan ajar kontekstual dan erat kaitannya dengan pemahaman mengenai aspek lingkungan secara alami (DIKTI, 2008). Pengembangan sumber belajar tersebut perlu pula dilakukan pada mata kuliah Ekologi, yang merupakan mata kuliah wajib bagi mahasiswa semester IV Program Studi S1 Pendidikan Biologi FMIPA Universitas Negeri Gorontalo.Bahan ajar yang dapat dimanfaatkan mahasiswa sebagai sumber belajar mandiri mempunyai peranan penting dalam meningkatkan hasil belajar. Pengembangan bahan ajar yang tepat dan sesuai dengan kebutuhan masyarakat belajarnya adalah usaha terbaik untuk meningkatkan hasil belajar. Hal ini telah terbukti dari salah satu penelitian bahwa hasil belajar siswa yang diajarkan dengan menggunakan bahan ajar yang dirancang sesuai dengan kebutuhan dan keadaan peserta didik menunjukkan peningkatan hasil belajar yang signifikan (Ekawarna, 2013).

Berdasarkan analisis kebutuhan yang diuraikan di atas, maka pembelajaran mata kuliah Ekologi di Prodi Pendidikan Biologi FMIPA Universitas Negeri Gorontalo belum sejalan dengan Kurikulum dan tuntutan pendidikan saat ini yang mana bahwa salah satu prinsip pembelajaran yang dilaksanakan harus bersifat mendalam dan komprehensif melalui kemampuan berpikir kritis, induktif, dan deduktif untuk menyelesaikan masalah (Afandi dkk, 2012).

Belum adanya buku ajar yang menyinggung secara mendalam tentang potensi serapan karbon pada substrat mangrove secara umum, dan potensi mangrove sebagai penyimpan karbon terbanyak secara khusus dalam perkuliahan Ekologi dan kegiatan praktikum Ekologi di Program Studi Pendidikan Biologi FMIPA Universitas Negeri Gorontalo, maka dituntut perlunya pengembangan buku ajar ekologi pada sub pokok bahasan materi dan energi.

Permasalahan selanjutnya adalah bahwa materi yang dikemas dalam bahan ajar selama ini hanya berisi konsep-konsep, sifatnya abstrak, dihimpun dari berbagai sumber, dan bukan pengalaman atau temuan nyata dosen dari hasil penelitiannya. Bahan ajar yang dikembangkan berdasarkan hasil penelitian sifatnya akan lebih kontekstual, lebih dalam, dan lebih menarik karena tidak hanya teori atau konsep saja, tetapi berdasarkan fakta yang terbukti secara ilmiah, oleh karena itu, buku ajar Ekologi perlu dikembangkan dari hasil penelitian yang dilakukan.

Adanya buku ajar Ekologi yang mencakup hasil temuan melalui penelitian diharapkan dapat meningkatkan motivasi, kompetensi, dan prestasi belajar mahasiswa. Adanya bahan ajar 
yang memanfaatkan potensi ekosistem mangrove sebagai daerah serapan karbon terbesar yang merupakan suatu inovasi dalam dunia pendidikan yang harus terus dikembangkan.

Keberadaan bahan ajar tanpa memperhatikan pendekatan dalam mengembangkan materi dari buku ajar tersebut tidak akan membawa manfaat besar. Pendekatan yang tepat dalam pengembangan bahan ajar sangat dibutuhkan. Salah satu pendekatan belajar yang selama ini dianggap cocok untuk pembelajaran materi-materi abstrak adalah pendekatan kontekstual. Pendekatan ini dapat menjembatani pengetahuan teori dengan pengalaman nyata (Cartono, 2007) sehingga mampu menarik perhatian dan minat mahasiswa untuk menelaah dan memperdalam pemahaman mereka terhadap konsep yang dipelajarinya. Berdasarkan uraian permasalahan diatas maka diangkat judul penelitian sebagai berikut : "Pengembangan Buku Ajar Ekologi Dengan Memanfaatkan Hasil Analisis Potensi Ekosistem Mangrove Sebagai Penyerap Karbon ”

\section{Metodologi}

Penelitian ini dilaksanakan di Jurusan Biologi pada Smester genap tahun pelajaran 2017-2018. Waktu penelitian dilaksanakan bulan Maret sampai bulan juli, 2017 mulai dari penyusanan proposal sampai penyusunan Tesis.

penelitian ini dirancang dalam bentuk penelitian pengembangan (research and development atau $\mathrm{R} \&$ D), yaitu suatu penelitian yang dilakukan dengan tujuan menghasilkan sebuah model, baik dalam bentuk perangkat keras (atau hardware) maupun perangkat lunak (software). Dalam penelitian ini produk yang dihasilkan adalah buku ajar pada mata kuliah ekologi pokok bahasan materi dan energy. Pengembangan Buku ajar tersebut dimaksudkan untuk meningkatkan pembelajaran ekologi untuk menunjang ketercapaian kompetensi mahasiswa dalam menjelaskan arus energi dan siklus materi dalam suatu ekosistem.

Proses penelitian pengembangan ini ditempuh melalui 10 langkah sebagaimana yang dikemukakan oleh Borg dan Gall (1989), yakni (1) mengumpulkan informasi dan melakukan penelitian awal (research andinformation collecting), (2) perencanaan (planning), (3) mengembangkan format atau model (developing preliminary form of product), (4) mempersiapkan uji coba tes di lapangan (preliminary field testing), (5) melakukan revisi terhadap tes berdasarkan hasil uji coba di lapangan (main product revision), (6) melakukan tes di lapangan (main field testing) (7) melakukan revisi setelah mendapatkan masukan dari tes lapangan (operational product revisions), (8) melaksanakan tes uji coba model atau tes pembelajaran (operational field testing), (9) melakukan revisi terakhir (final product revision), (10) menyampaikan laporan penelitian (dominition and implementation).

Desain penelitian yang telah dikemukakan tersebut kemudian di sederhanakan atas tiga tahap, yaitu (1) tahap eksplorasi, (2) tahap pengembangan prototipe, dan (3) tahap validasi produk, adapun produk yang dihasilkan dalam penelitian ini adalah buku ajar (Faridi, 2008). Pengelompokan menjadi tiga tahap tersebut hanya untuk memudahkan dalam proses penelitian, sama skali tidak mengurangi makna dari masing-masing langkah yang sebenarnya.

Instrumen yang digunakan dalam penelitian ini adalah angket yang diberikan kepada ahli konten/materi, ahli desain, dan mahasiswa jurusan biologi semester 4 yang memprogramkan mata kuliah ekologi sebagai respondennya.

Penelitian pengembangan materi buku ajar berbasis potensi lokal ini menggunakan analisis data deskriptif kualitatif untuk mendeskripsikan hasil studi pendahuluan dan hasil rancangan produk serta saran perbaikan dari validator, dosen biologi dan mahasiswa sebagai pengguna buku ajar. Selanjutnya data mengenai kualitas buku ajar berdasarkan penilaian validator ahli, Dosen ekologi dan mahasiswa dianalisis melalui pengubahan dari bentuk kualitatif ke bentuk kuantitatif dengan ketentuan sebagai berikut 
Tabel 2.1 Kategori Skala Likert

\begin{tabular}{cc}
\hline Skor Nilai & Interprestasi \\
\hline $\mathbf{4}$ & Sangat Layak \\
\hline $\mathbf{3}$ & Layak \\
\hline $\mathbf{2}$ & Tidak Layak \\
\hline $\mathbf{1}$ & Sangat Tidak Layak
\end{tabular}

a. Menghitung skor rata-rata dari setiap aspek yang dinilai dengan rumus :

$X=\frac{\sum \mathrm{x}}{\mathrm{n}}$

Keterangan: $\quad \mathrm{X}=$ skor rata-rata

$\Sigma \mathrm{x}=$ jumlah skor

$\mathrm{n}=$ jumlah review

b. Mengubah skor rata-rata setiap aspek menjadi nilai sesuai kriteria penilaian.

Table 2.2 Rentang skor validitas

\begin{tabular}{ccc}
\hline No & Rentang skor & Kategori \\
\hline 1 & $\mathrm{X}>\mathrm{Mi}+1,80 \mathrm{SBi}$ & $\begin{array}{c}\text { Sangat } \\
\text { valid }\end{array}$ \\
\hline 2 & $\mathrm{Mi}+0,6 \mathrm{SBi}<\mathrm{X} \leq$ & Valid \\
& $\mathrm{Mi}+1,80 \mathrm{SBi}$ & \\
\hline 3 & $\mathrm{Mi}-0,6 \mathrm{SBi}<\mathrm{X} \leq$ & $\begin{array}{c}\text { Cukup } \\
\text { valid }\end{array}$ \\
& $\mathrm{Mi}+0,60 \mathrm{SBi}$ & Kurang \\
4 & $\mathrm{Mi}-1,80 \mathrm{SBi}<\mathrm{X} \leq$ & valid \\
& $\mathrm{Mi}-0,60 \mathrm{SBi}$ &
\end{tabular}

Sumber: Rahmawati, 2013

Keterangan :

Mi $=$ Mean Ideal $=1 / 2 \times$ (skor tertinggi ideal + skor terendah ideal $)$

$\mathrm{SBi}=$ Simpangan Baku Ideal $=(1 / 2) \times(1 / 3) \times($ skor tertinggi ideal - skor terendah ideal $)$

Skor tertinggi ideal $=\Sigma$ butir kriteria $\mathrm{x}$ skor tertinggi

Skor terendah ideal $=\Sigma$ butir kriteria $\mathrm{x}$ skor terendah

c. Presentasi Ideal

presentasi ideal $(\mathrm{p})=\frac{\text { skor hasil penilaian }}{\text { skor maksimal penilaian }} \times 100 \%$

Identifikasi presentasi ideal digunakan empat kategori yaitu sangat baik, cukup dan kurang.

Pengidentifikasian dilakukan dengan menggunakan ketentuan sebagai berikut:

\begin{tabular}{ccc}
\hline No & Interval & Kriteria \\
\hline 1 & $81 \%-100 \%$ & Sangat baik \\
\hline 2 & $61 \%-80 \%$ & Baik \\
\hline 3 & $41 \%-60 \%$ & Cukup \\
\hline
\end{tabular}




$4 \quad 21 \%-40 \% \quad$ Kurang

Sumber : Rahmawati, 2013.

\section{Hasil dan Pembahasan}

\section{A.Hasil Penelitian}

Penelitian mengenai pengembangan model buku ajar pada mata kuliah ekologi Pokok bahasan : Materi dan Energi di jurusan pendidikan biologi FMIPA merupakan suatu kajian yang menghasilkan buku ajar yang siap digunakan dalam proses pembelajaran Ekologi di tingkat perguruan tinggi. Buku ajar tersebut dikembangkan dengan mengacu pada kebutuhan Dosen dalam pembelajaran ekologi yang merupakan salah satu mata kuliah wajib di jurusan pendidikan biologi FMIPA. Buku ajar yang telah digunakan selama ini yang merupakan pegangan dosen kemudian dianalisis untuk dicari kelemahan dan kelebihannya. Kelebihan dan kelemahan yang ditemukan dalam buku ajar tersebut akan digunakan sebagai masukan pada pengembangan model buku ajar yang dirancang. Meskipun demikian, pengembangan buku materi ajar tersebut didasarkan pula pada hasil research dan teori-teori yang relevan dalam pengembangan buku ajar terkait potensi ekosistem mangrove sebagai daerah serapan karbon.

Berdasarkan hasil studi literatur dan penelusuran hasil research mahasiswa S1 pendidikan biologi FMIPA Universitas Negeri Gorontalo dan jurnal terkait analisis karbon di peroleh informasi bahwa Kawasan pesisir dan laut di provinsi Gorontalo merupakan sebuah ekosistem yang terpadu dan saling berkolerasi secara timbal balik. Di dalam suatu ekosistem pesisir terjadi pertukaran materi dan transformasi energi yang berlangsung dalam sistem tersebut maupun dengan komponen-komponen sistem lain di luarnya. Kelangsungan suatu fungsi ekosistem sangat menentukan kelestarian sumberdaya alam sebagai komponen yang terlibat di dalamnya (Bengen, 2002). Salah satu ekosistem utama di wilayah pesisir dan lautan adalah ekosistem hutan bakau atau hutan mangrove.

Berdasarkan hasil penelitian Lapolo (2014) potensi nilai biomassa mangrove spesies Avicennia marina (Forsk.) Vierh. di muara sungai Popayato Kecamatan Popayato Kabupaten Pohuwato yakni dengan nilai biomassa batang adalah $12.816 \mathrm{~kg}$, nilai biomassa akar yakni 4.853,7 kg dan biomassa total yakni $17.670 \mathrm{~kg}$. Tegakan mangrove Avicennia marina (Forsk.) Vierh. memiliki kandungan karbon total sebesar $8.835 \mathrm{~kg}$, dengan nilai serapan karbondioksida $\left(\mathrm{CO}_{2}\right)$ adalah $32.424 \mathrm{~kg}$ atau dirata ratakan serapan karbondioksida yaitu $1.118,1 \mathrm{~kg} \mathrm{CO}_{2} /$ pohon. Hasil penelitian Linggula (2014) bahwa potensi nilai biomassa mangrove spesies Rhizophora mucronata Lamk. di wilayah pesisir Desa Torosiaje yaitu sebesar 25.361,4 kg. Dari nilai biomassa tersebut diperoleh kandungan karbon Rhizophora mucronata Lamk. sebesar 12.680,71 kg dan serapan karbon yaitu sebesar 46.538,19 kg. Berdasarkan hasil penelitian di Kawasan Mangrove Desa Mootinelo oleh Sugeha (2014) Potensi Biomassa dan Karbon Bawah Permukaan (akar) pada Avicennia marina lebih tinggi biomassanya 11,75 ton/ha (rerata diameter $34,45 \mathrm{~cm}$ ) setara dengan 5,5413 ton C/ha atau 20,3366 ton CO2/ha. Sementara jenis Avicennia alba berada di urutan kedua dengan jumlah biomassa 1,51 ton/ha (rerata diameter $30,8 \mathrm{~cm}$ ) setara dengan 0,7097 ton $\mathrm{C} /$ ha atau 2,6046 ton $\mathrm{CO} 2 /$ ha. Adapun estimasi kandungan karbon substrat berdasarkan keseluruhan pohon sampel adalah $1842.435 \mathrm{gr} \mathrm{C} / \mathrm{cm} 2$ atau 1842.435 ton $\mathrm{C} / \mathrm{ha}$.

Upaya yang dilakukan terkait pengukuran potensi ekosistem mangrove tersebut memberikan gambaran bahwa pengembangan model buku ajar dirancang tidak serta merta disusun menjadi buku ajar yang asal jadi. Untuk itu, upaya penyelarasan buku ajar yang dibuat berdasarkan hasil research dan kebutuhan Dosen serta landasan teoretis yang akan memberikan peluang yang lebih komprehensif dalam menciptakan buku ajar yang berkualitas dan berdaya guna dalam pembelajaran ekologi pada tingkat Universitas. Rancangan model buku ajar yang dikembangkan ini disusun dengan tiga tahap, yakni (1) tahap eksplorasi, (2) tahap pengembangan prototipe buku ajar, dan (3) tahap validasi model. Tahap-tahap tersebut lebih lanjut dipaparkan pada bagian berikut.

\section{a. Tahap Eksplorasi}

Masalah penting yang sering dihadapi Dosen dalam kegiatan pembelajaran adalah memilih atau menentukan materi pembelajaran atau bahan ajar yang tepat dalam rangka membantu mahasiswa dalam mencapai kompetensi. Hal ini disebabkan oleh kenyataan bahwa dalam kurikulum atau silabus, materi ajar hanya dituliskan secara garis besar dalam bentuk "materi pokok". Tugas dosen adalah untuk menjabarkan materi pokok tersebut menjadi materi ajar yang lengkap. Selain itu, bagaimana cara 
memanfaatkan buku ajar juga merupakan masalah. Pemanfaatan yang dimaksud adalah bagaimana cara mengajarkannya ditinjau dari pihak Dosen, dan cara mempelajarinya ditinjau dari pihak mahasiswa.

Pada tahap ini dilakukan analisis tujuan sesuai dengan standar kompetensi umum pada silabus perkuliahan (SAP) yang yaitu mampu memahami dan mengaplikasikan konsep-konsep ekologi, prinsip-prinsip interaksi antara organisme dengan lingkungannya, konsep populasi, komunitas, ekosistem, keanekaragaman hayati, suksesi, aliran energi dan siklus materi dan strategi serta metodemetode dan analisis sampling dalam ekologi dengan benar. Kompetensi khusus meliputi (1) mampu menjelaskan arus energy dan siklus materi, kompetensi dasar meliputi : (a) Arus energy dan materi, (b) siklus karbon, langkah pokok dalam tahapan ini meliputi analisis yang memunculkan masalah dasar yang dibutuhkan dalam mengembangkan buku ajar. Survey yang dilakukan terhadap beberapa mahasiswa yang memprogramkan mata kuliah ekologi pada smester empat (4) peneliti menemukan adanya kurang pemahaman mahasiswa terhadap materi mengenai daur biogeokimia khususnya menyangkut siklus karbon.

Proses selanjutnya analisis peneliti terhadap isi materi dalam buku ajar lebih khusus pada materi siklus karbon, peneliti tidak menemukan penjelasan secara lengkap bagaimana aplikasi dan tata cara menghitung potensi serapan karbon pada ekosistem mangrove, materi yang dikemas dalam buku ajar hanya focus pada teori dan konsep-konsep lebih umum.

\section{b. Pengembangan Prototype Draft Buku Ajar}

Dasar penyusunan yang digunakan adalah hasil studi pendahuluan, landasan memanfaatkan buku ajar juga merupakan masalah. Pemanfaatan yang dimaksud adalah bagaimana cara mengajarkannya ditinjau dari pihak Dosen, dan cara mempelajarinya ditinjau dari pihak mahasiswa.

Pada tahap ini dilakukan analisis tujuan sesuai dengan standar kompetensi umum pada silabus perkuliahan (SAP) yang yaitu mampu memahami dan mengaplikasikan konsep-konsep ekologi, prinsip-prinsip interaksi antara organisme dengan lingkungannya, konsep populasi, komunitas, ekosistem, keanekaragaman hayati, suksesi, aliran energi dan siklus materi dan strategi serta metodemetode dan analisis sampling dalam ekologi dengan benar. Kompetensi khusus meliputi (1) mampu menjelaskan arus energy dan siklus materi, kompetensi dasar meliputi : (a) Arus energy dan materi, (b) siklus karbon, langkah pokok dalam tahapan ini meliputi analisis yang memunculkan masalah dasar yang dibutuhkan dalam mengembangkan buku ajar. Survey yang dilakukan terhadap beberapa mahasiswa yang memprogramkan mata kuliah ekologi pada smester empat (4) peneliti menemukan adanya kurang pemahaman mahasiswa terhadap materi mengenai daur biogeokimia khususnya menyangkut siklus karbon.

Proses selanjutnya analisis peneliti terhadap isi materi dalam buku ajar lebih khusus pada materi siklus karbon, peneliti tidak menemukan penjelasan secara lengkap bagaimana aplikasi dan tata cara menghitung potensi serapan karbon pada ekosistem mangrove, materi yang dikemas dalam buku ajar hanya focus pada teori dan konsep-konsep lebih umum.

\section{c. Pengembangan Prototype Draft Buku Ajar}

Dasar penyusunan yang digunakan adalah hasil studi pendahuluan, landasan setiap aspek penilaian yang diberikan oleh validator ahli materi dan ditentukan rentang skor validasi dengan menghitung nilai rata-rata terlebih dahulu untuk setiap aspek maupun secara keseluruhan. Berdasarkan hasil perhitungan kualitas buku ajar secara keseluruhan didapatkan nilai $\mathrm{X}<48$. Sehingga skor validasi berada dalam kategori valid.

Analisis data selanjutnya adalah dengan menghitung persentase keidealan produk buku ajar untuk setiap aspek maupun keseluruhan. Persentase untuk setiap aspek yakni aspek format materi dengan nilai 87,5 \% (Sangat baik), kelayakan aspek isi materi dengan nilai $96.43 \%$ (Sangat baik), dan kualitas aspek penilaian dengan nilai 91,67\% (sangat baik). Persentase keidealan secara keseluruhan oleh ahli materi yaitu 93,75\% (sangat baik). Berdasarkan hasil tersebut terlihat bahwa persentase keseluruhan aspek dari penilaian validator ahli materi berada pada rentang $81 \%-100 \%$ termasuk dalam kategori sangat baik.

\section{Uji Validitas dari Ahli Desain}

Tahap selanjutnya dalam pengembangan buku ajar. Pada tahap ini media divalidasi oleh 1 orang ahli desain yaitu Dosen Jurusan Biologi FMIPA UNG, Bapak Dr. Hartono, D. Mamu, M,Pd Masukan dan saran dari ahli media akan dijadikan dasar untuk revisi media agar media yang dikembangkan menjadi lebih baik lagi. 
Validasi yang dilakukan oleh ahli media yaitu dengan mengumpulkan saran atau pendapat untuk melakukan revisi. Berdasarkan saran atau pendapat dari ahli media, dilakukan revisi untuk membuat media pembelajaran dalam hal ini buku ajar menjadi lebih baik lagi. Adapun saran dan revisi perbaikan dari ahli media yaitu:memperbaiki tata cara penulisan buku ajar, materi sebaiknya diawali dengan kompetensi dasar dan indicator, diakhir uraian materi ditambahkan poin untuk soal-soal berdasarkan indkator, selanjutnya penulisan daftar pustaka memperhatikan panduan penulisan. Berbagai saran tersebut ditindaklanjuti agar buku ajar yang ada menjadi buku ajar yang lebih berkualitas. Tahap selanjutnya yaitu menghitung skor setiap aspek penilaian yang diberikan oleh validator ahli desain dan ditentukan rentang skor validasi dengan menghitung nilai rata-rata terlebih dahulu untuk setiap aspek maupun secara keseluruhan. Berdasarkan hasil perhitungan kualitas buku ajar secara keseluruhan didapatkan nilai $\mathrm{X}<48$. Sehingga skor validasi berada dalam kategori valid.

Analisis data selanjutnya adalah dengan menghitung persentase keidealan produk buku ajar untuk setiap aspek maupun keseluruhan. Persentase untuk setiap aspek yakni aspek tampilan cover dengan nilai 93,75 \% (Sangat baik), kelayakan aspek tampilan materi dengan nilai 90.63\% (Sangat baik). Persentase keidealan secara keseluruhan oleh ahli desain yaitu 91,67 \% (sangat baik). Berdasarkan hasil tersebut terlihat bahwa persentase keseluruhan aspek dari penilaian validator ahli materi berada pada rentang $81 \%-100 \%$ termasuk dalam kategori sangat baik.

\section{Penilaian Buku oleh Peserta didik (Mahasiswa)}

Penilaian buku ajar oleh peserta didik (Mahasisawa) bertujuan untuk melihat respon peserta didik dari aspek kemenarikan buku yang dikembangkan, dari segi kemudahan penggunaan buku ajar dan dari segi keterbacaan. Berdasarkan hasil penilaian peserta didik dapat diidentifikasi bahwa rata-rata secara keseluruhan buku ajar (X) yakni sebesar 37,6. Nilai tersebut lebih kecil dibandingkan dengan nilai $\mathrm{Mi}+1,80 \mathrm{SBi}(\mathrm{X}>\mathrm{Mi}+1,80 \mathrm{SBi})$, sehingga dapat dikatakan bahwa penilaian oleh peserta didik terletak pada kategori valid. Selanjutnya dengan menghitung persentase keidealan produk buku ajar untuk setiap aspek maupun keseluruhan. Persentase keidealan secara keseluruhan yakni sebesar 94\% (Sangat Baik). Sementara itu untuk setiap aspek yakni aspek kemenarikan buku ajar95 \% (sangat baik), kemudahan penggunaan buku ajar 92,5\% (sangat baik) dan dari aspek keterbacaan buku ajar sebesar 97,17\% (sangat baik). Berdasarkan hasil perhitungan tersebut, terlihat bahwa presentase keseluruhan aspek dari ujikelompok kecil berada dalam rentang $81 \%$ - 100\% yang berarti tingkat keidealanbuku ajar potensi ekosistem mangrove sebagai penyerap karbon dalam kategori sangat baik.

Berdasarkan keseluruhan hasil penilaian yang dilakukan oleh validator ahli materi, validator ahli media, serta respon peserta didik dalam hal ini mahasiswa S1 pendidikan biologi pada Fakultas FMIPA Universitas Negeri Gorontalo dapat disimpulkan bahwa buku ajaryang merupakan hasil pengembangan dari hasil research mengenai potensi ekosistem mangrove sebagai penyerap karbon layak/valid digunakan dalam proses pembelajaran.

\section{B. Pembahasan}

Ekologi merupakan mata kuliah wajib bagi mahasiswa Program Studi Pendidikan Biologi FMIPA, Universitas Negeri Gorontalo. Matakuliah Ekologi ditempuh pada semester IV. Matakuliah Ekologi dideskripsikan sebagai ilmu yang memaparkan tentang penerapan dan pengembangan prinsipprinsip ekologi dalam kebermaknaan hidup dan penelitian (Sukarsono, 2012). Ekologi mengkaji hewan maupun tumbuhan sebagai salah satu organisme hidup yang menempati suatu habitat atau wilayah untuk hidup tumbuh, berkembang dalam mempertahankan generasinya.

Menurut Susanto (2000) ekologi menyangkut 3 aspek pokok, yaitu: 1) deskriptif, 2) kuantitatif, dan 3) analitik-sintetik. Ekologi deskriptif menyangkut pengetahuan tentang cara hidup , yaitu meliputi tingkah laku, habitat, kondisi lingkungan hidup, hubungan dengan jenis lain, karakteristik kelompok sosialnya, dominansinya, asal mula dansuksesi pembetukan komunitasnya. Ekologi kuantitatif memberikan informasi yang menyangkut tentang ukuran-ukuran kondisi lingkungan dan batas-batas toleransi terhadap fluktuasi faktor lingkungan, jumlah, dan macam jenis yang bertahan hidup dalam habitat tertentu. Ekologi analitik-sintetik berusaha menganalisis lingkungan beserta pengaruhnya dengan cara memvariasikan kondisi faktor tertentu di bawah kondisi faktor lain yang terkontrol, menganalisis mengapa mempunyai habitat spesifik, mengapa berkembang, mengapa punah, dan mengapa beradaptasi dengan lingkungan baru.

Buku Ajar sebagai hasil pengembangan memuat materi yang dapat memperkaya buku teks pada jenjang pendidikan perguruan tinggi. Buku ajar yang dimaksud adalah memberikan informasi 
tentang pokok-pokok bahasan tertentu dalam kurikulum secara lebih luas atau lebih dalam. Buku ajar disebut juga buku pelajaran pelengkap yang berisi informasi untuk melengkapi buku pelajaran pokok. Pendapat tersebut sejalan dengan Cintamulya (2011) yang mengungkapkan bahwa buku ajar memuat materi yang dapat memperkaya dan meningkatkan penguasaan IPTEK dan keterampilan pembaca. Buku jenis ini tidak sematamata untuk peserta didik namun dapat digunakan masyarakat umum. Buku ajar digunakan pendidik untuk memperkaya proses pembelajaran.

Buku ajar yang digunakan di Program Studi Pendidikan Biologi FMIPA Universitas Negeri Gorontalo sudah disusun hampir 10 tahun. Petunjuk praktikum yang ada pun sudah dipakai selama bertahun-tahun bahkan puluhan tahun, dan rasanya belum pernah ditinjau ulang. Mengingat perkembangan zaman dan tren ilmu pengetahuan khususnya di bidang ekologi maka tidak salah rasanya bila perlu penyegaran materi dalam buku ajarini. Menurut Husamah (2013) disepakati bahwa semua pihak perlu terlibat untuk meninjau ulang buku teks yang telah disusun guna mencapai tujuan mulia yaitu mencetak calon guru biologi yang kompeten dan professional.

Sebagaimana umumnya ciri sebuah ilmu, ekologi adalah salah satu disiplin ilmu yang terus berkembang. Oleh karena itu buku ajar akan terus mengalami berbagai perkembangan menuju arah perbaikan (Sukarsono, 2013). Belum adanya adanya materi mengenai fugsi mangrove sebagai penyerap karbon dalam perkuliahan Ekologi dan kegiatan praktikum ekologi hewan di Program Studi Pendidikan Biologi FMIPA Universitas Negeri Gorontalo menuntut perlunya pengembangan buku ajar berbasis penelitian sehingga semakin memperkaya pemahaman mahasiswa. Hal ini sejalan dengan KBK dan tuntutan pendidikan saat ini yang menyatakan bahwa salah satu prinsip pembelajaran harus mendalam dan komprehensif melalui kemampuan berpikir kritis, induktif, dan deduktif untuk menyelesaikan.

Kesulitan yang dialami mahasiswa dalam memahami materi ekologi biasanya adalah memahami terminologi dan prinsip-prinsip mengingat tidak cukupnya ilustrasi yang dapat membantu mereka merangkai pikiran secara cepat informasi baru dengan informasi yang belum tersedia dalam pikiran. Oleh karena itu, penulis berusaha menyajikan informasi mengenai materi dalam buku ajar dengan beberapa tampilan gambar sehingga diharapkan materi akan lebih cepat dipahami oleh para mahasiswa.

Buku ajar yang dikembangkan ini telah sejalan dengan pendapat Suhardjono (2008) namun memiliki nilai lebih atau tambah karena juga memuat hasil penelitian penulis sendiri. Buku peganyaan ini pun diperkaya dengan panduan pengamatan atau penelitian, sehingga para mahasiswa atau pembaca dapat menerapkannya atau dapat melakukan penelitian dengan merujuk pada buku ajar ini.

\section{Kesimpulan}

Berdasarkan hasil penilitian dan pengembangan dapat disimpulkan bahwa kualitas buku ajar berdasarkan hasil validitas oleh validator ahli materi menunjukan prosentase keidealan secara keseluruhan yaitu 93,75\% dengan kategori (sangat baik), sedangkan validitas oleh ahli desain media menunjukan prosentase keidealan secara keseluruhan sebesar 91,67\% dengan kategori (sangat baik), sedangkan hasil respon peserta didik dalam hal ini mahasiswa menunjukan keidealan sebesar $94 \%$ (sangat baik), keseluruhan penilaian validitas yang dilakukan oleh validator ahli materi, ahli desain maupun respon peserta didik atau mahasiswa dapat disimpulkan bahwa buku ajar potensi ekosistem mangrove sebagai daerah serapan karbon yang merupakan pengembangan dari buku ajar ekologi jurusan S1 Pendidikan biologi FMIPA Universitas Negeri Gorontalo pokok bahasan materi dan energy layak/valid dan dapat digunakan dalam proses pembelajaran ataupun perkuliahan.

\section{Saran}

Berdasarkan kesimpulan di atas peneliti menyarankan Dosen pengampuh mata kuliah ekologi dapat menggunakan buku ajar yang telah dikembangkan sebagai pendamping sehingga memperkaya materi yang disampaikan dalam pembelajaran dikelas maupun dalam laboratoriun (praktikum). Dosen hendaknya selalu kreatif dan inovatif dalam penyusunan bahan ajar, khususnya buku ajar yang lebih menarik. 


\section{Referensi}

Afandi, dkk. (2012). Pembelajaran Biologi Menggunakan Pendekatan Metakognitif melalui Model Reciprocal Learning dan Problem Based Learning Ditinjau Dari Kemandirian Belajar dan Kemampuan Berfikir Kritis Mahasiswa. Jurnal Inkuiri. ISSN 22527893 Vol. 1 No.2

Bismark, M., Endro Subiandono dan N.M. Heriyanto. 2008. Keragaman Dan Potensi Jenis Serta Kandungan Karbon Hutan Mangrove Di Sungai Subelen Siberut, Sumatera Barat (Diversity, Potential Species and Carbon Content of Mangrove Forest at Subelen River, Siberut, West Sumatra**). Jurnal Penelitian Hutan dan Konservasi Alam (Online), Vol. V No. 3 : 297-306, 2008.( Bengen, D. 2002. Pengenalan dan Pengelolaan Ekosistem Mangrove. Bogor. Pusat Kajian Sumber Daya Pesisir dan Kelautan Institut Pertanian Bogor.

Borg, Walter R, Meredith Damin Gal. 1989. Educational Recearch : An Introduction . University of Oregon Seventh Edition: Boston New York

Cintamulya, I. 2011. Analisis Variasi Genetik Varian Jati Arboretum dengan Penanda Mikrosatelit sebagai Bahan untuk Menyusun Buku Pengayaan Kajian Dasar-Dasar Molekuler Tumbuhan. Disertasi tidak diterbitkan. Malang: Pascasarjana UM.

Cartono, 2007. Metode dan Pendekatan Dalam Pembelajaran Sains. Bandung : PPS UPI.

Donato C. Daniel, J. Boone Kauffman, Daniel Murdiyarso, Sofyan Kurnianto, Melanie Stidham dan Markku Kanninen. 2012. Februari. Brief Cifor (Online). H. 1-7. (http://www.cifor.org, diakses 28 Oktober 2013).

Ekawarna.2013. Evalusi Hasil Belajar. Bandung : Media Persada.

Faridi, Abdurrachman. 2008, Pengembangan Model Materi Ajar Muatan Lokal Bahasa Inggris di Sekolah Dasar Jawa Tengah Yang Berwawasan Sosiokultural. Disertasi Program Pascasarjana : Universitas Negeri Semarang.

Ghufran, H.K.K.M. 2012. Ekosistem Mangrove: Potensi, Fungsi dan Pengelolaan. Jakarta: Rineka Cipta

Husamah. 2013. Materi Tambahan Penguatan Kompetensi Praktikum Ekologi di Laboratorium Biologi UMM.

Makalah disajikan pada Training Asisten LaboratoriumBiologi, Kampus III UMM, Malang, 26 Desember.

Lapolo, Nurain.2014 Potensi Nilai Biomassa Mangrove Spesies Avicennia marina (Forsk.) Vierh. di Muara Sungai Popayato Kabupaten Pohuwato. Skripsi Jurusan Pendidikan Biologi : Universitas Negeri Gorontalo.

Oktavianus, Satria. 2013. Uji Daya Hambat Ekstrak Daun Mangrove Jenis Avicennia marina Terhadap Bakteri Vibrio parahaemolyticus. Skripsi Makassar: Jurusan Ilmu Kelautan Fakultas Ilmu Kelautan Dan Perikanan Universitas Hasanuddin Makassar.

Rahmawati, Estiana. 2013. Pengembangan Lembar Kerja Siswa (LKS) Interaktif Berbasis Website Materi Jamur (Fungi) untuk Siswa.

Sugeha, Reynaldi. 2015 Potensi Serapan Karbon pada Akar dan Substrat Mangrove Genus Avicennia di Desa Mootinelo Kecamatan Kwandang Kabupaten Gorontalo Utara. Skripsi Jurusan Pendidikan Biologi : Universitas Negeri Gorontalo.

Sukarsono. 2012. Pengantar Ekologi: Konsep, Perilaku, Psikologi dan Komunikasi.Malang: UMM Press.

Susanto, P. 2000. Pengantar Ekologi. Jakarta: Proyek Pengembangan Guru

Suhardjono, 2001, Pedoman Penyusunan Karya Tulis Ilmiah di Bidang Pendidikan Pengembangan Profesi. Universitas Brawijaya Malang.

Tamooh, F., M. Huxham., M. Karachi., M. Mencuccini., J.G. Kairo., B. Kirui. 2008. Below-ground root yield and distribution in natural and replanted mangrove forests at Gazi bay, Kenya. Journal Forest Ecology and Management 256 (2008) 1290-1297 Elsevier. (Online). (http://www.elsevier.com/locate/foreco, diakses 25 Desember 2015.

SMA/MA Kelas X Semester I. Skripsi. Program Studi Pendidikan Biologi Fakultas Sains dan Teknologi UIN Sunan Kalijaga Yogyakarta. Yogyakarta. 